\title{
Innføring av studentaktive arbeidsformer i seminarundervisningen. Hvilken betydning har dette på læringsutbyttet og klassemiljøet?
}

\author{
Kjell Ø. Netland ${ }^{1}$, Annfrid Sivertsen ${ }^{2}$, og Magne Olufsen ${ }^{3}$, \\ ${ }^{1}$ Institutt for fysikk og teknologi, ${ }^{2}$ Institutt for kjemi, ${ }^{3}$ Institutt for lcererutdanning og pedagogikk, \\ UiT-Norges Arktiske Universitet
}

\section{Sammendrag}

I denne studien ønsket vi å undersøke hvordan innføring av studentaktive læringsformer i seminarundervisningen påvirket det faglige læringsutbyttet og klassemiljøet i STEM-fag (science, technology, engineering and mathematics). Et randomisert kontrollert studie ble gjennomført i seminarundervisningen i to innføringsemner i fysikk og kjemi ved UiT Norges arktiske universitet. I emnene fulgte halvparten av studentene seminarundervisning med studentaktive arbeidsformer, og resterende studenter fulgte seminarer med lærersentrert undervisning. Studentene ble gitt kunnskapstester og spørreundersøkelser både ved semesterstart og før eksamen, i tillegg til at eksamensresultatet ble innhentet. Det ble også gjennomført et fokusgruppeintervju av seminarlærerne som underviste de studentaktive seminarene.

Våre funn viser at både studenter og seminarlærere var fornøyde med omlegging til studentaktiv undervisning. Fra både student- og lærerperspektiv ble det begrunnet med at læringsaktivitetene la til rette for en god faglig diskusjon og skapte engasjement. Studentene var veldig positive til gruppediskusjon rundt grunnleggende faglige begreper, og uttrykte et høyt selvopplevd læringsutbytte fra slike aktiviteter. Vi fant at i fysikk fikk studentene som fulgte studentaktive seminarer en gjennomsnittlig 0,36 bedre karakter på eksamen enn kontrollgruppen, med samme observerte tendens på kunnskapstestene. I kjemi var både eksamenskarakter og resultat fra kunnskapstestene omtrent like mellom studentgruppene. Studien viser at både studenter og lærere mente omlegging til studentaktive seminarer førte til et bedre klassemiljø for studentene.

\section{Nøkkelord}

Studentaktiv læring - seminar - klassemiljø - læringsutbytte - høyere utdanning 


\section{Introduksjon}

Seminarundervisningen i introduksjonsemnene i fysikk og kjemi ved UiT Norges arktiske universitet har frem til nå i hovedsak vært lærersentrert, og det har i liten grad vært lagt opp til undervisning som fremmer studentaktivitet og samarbeid mellom studentene. I en typisk seminartime har det vært opp til studentene selv hvor mye de vil samarbeide. Seminarlærer har gjennomgått oppgaver i plenum og hjulpet enkeltelever med oppgaver.

\section{Seminarundervisning $i$ høyere utdanning}

Forelesninger for et større antall studenter, og seminarundervisning for mindre studentgrupper er ofte sentrale deler av undervisningsopplegget i høyere utdanning. På seminarer er det ofte et mål at studentene skal kunne diskutere og løse problemer sammen (Exley \& Dennick, 2004). Studiet til Hardman (2016) viser at diskusjonene i seminarundervisning ofte er dominert av læreren, og spørsmål fra læreren i mange tilfeller ikke lykkes i å øke studentenes begrepsmessige forståelse. Studentene vil i en slik lærerstyrt diskusjon i mindre grad initiere egne ideer i faget. Det er også stilt spørsmål om ensidig bruk av regneoppgaver i fysikk gir tilfredsstillende forståelse av lærestoffet (Angell et al., 2011). Seminarlæreren er ofte den underviseren som har mest kontakt med studentene, og vil i høy grad kunne påvirke studentenes faglige utvikling. For at seminarlærere skal kunne gi undervisning av høy kvalitet er det behov for oppfølging og profesjonell utvikling (Hardman, 2016). En studie av Derting et al. (2016) rapporterte at lærere i STEM-fagene (science, technology, engineering and mathematics) som deltok på et utviklingsprogram gjennomførte mer studentaktiv undervisning enn andre lærere. Denne studien tyder på at kompetanseheving hos seminarlærere kan endre undervisningspraksis.

\section{Studentaktiv og samarbeidsbasert undervisning}

Aktiv involvering av studentene i undervisningen i STEM-fagene har vist seg å kunne føre til økt læringsutbytte (Freeman et al., 2014; Hake, 1998) og særlig bedre begrepsmessig forståelse (Crouch \& Mazur, 2001). Omlegging til mer studentaktiv undervisning kan også gi økt engasjement, motivasjon og oppmøte i undervisningen (Luke, Duun \& Christie, 2017). Vi har valgt følgende definisjon på studentaktiv undervisning:

Active learning engages students in the process of learning through activities and/or discussion in class, as opposed to passively listening to an expert. It emphasizes higher-order thinking and often involves group work (Freeman et al., 2014, s. 4-5).

Studentaktive arbeidsformer inneholder i mange tilfeller en eller annen form for samarbeidslæring. Målet med samarbeidslæring er å nå læringsmålene gjennom diskusjon og tilbakemeldinger fra andre medstudenter (Foldnes, 2016). Studier viser at innføring av samarbeidslæring i høyere utdanning kan øke studentenes læringsutbytte (Chace, 2014; Foldnes, 2016). Bruk av metoder som fremmer samarbeid har også vist seg å øke studentenes engasjement (Cavanagh, 2011; Herrmann, 2013). Samarbeidslæring er mest effektiv dersom studentene opplever å nå felles mål, og når den enkelte students mål avhenger av gruppens aktivitet (Herrmann, 2013).

I undervisning som vektlegger samarbeidslæring blir det muntlige språket en viktig faktor for å konstruere kunnskap (Leach \& Scott, 2003). Henriksen og Angell (2010) argumenterer for at undervisning hvor studentene diskuterer fysikk i små grupper fører til bedre fagforståelse. 


\section{Forskningsspørsmål}

Basert på det vi vet om studentaktive arbeidsmåters positive effekt på studentenes læringsutbytte og erfaringer fra egen undervisning, ønsket vi å sammenligne studentaktive seminarer (testgrupper) med mer tradisjonell og lærerstyrt seminarundervisning (kontrollgrupper). I de studentaktive seminarene brukte vi de tre arbeidsformene begrepsoppgaver, speed-date og Pick me! Disse arbeidsformene vektla i høy grad samarbeid mellom studentene og er beskrevet i metodedelen.

Fra dette kom vi fram til følgende forskningsspørsmål:

a. Vil studenter som deltar på studentaktive seminarer oppnå et høyere læringsutbytte sammenlignet med studenter som følger lærersentrert seminarundervisning?

b. I hvilken grad vil innføring av studentaktive seminar påvirke klassemiljøet?

\section{Metode}

For å svare på forskerspørsmålene ble et randomisert kontrollert studie gjennomført. Studien ble gjennomført over ett semester i et innføringsemner i fysikk og i et innføringsemne i kjemi ved UiT Norges arktiske universitet. I begge emnene er det både regneferdigheter og mange begreper som skal læres. Emnene tas vanligvis tidlig i studieløpet av studenter på ulike realfaglige studieprogram. Undervisningen i begge emnene består av fire timer forelesning og to timer seminarundervisning per uke. Det var også et tilbud om frivillige støttetimer i begge emnene. I kjemi var det i tillegg et laboratoriekurs. Begge emner har skriftlig skoleeksamen som vurderingsform og her blir det både testet forståelsen av begreper og regneferdigheter.

\section{Utvalg}

Alle studentene som fulgte seminarundervisningen fikk tilbud om å være med i studien. I kjemi hadde studentene obligatorisk oppmøtekrav på minimum $10 \mathrm{av} 14$ seminarer, slik at alle studentene i emnet var potensielle respondenter. I fysikk var det frivillig oppmøte på seminarene, og 94 studenter hadde minst ett oppmøte på seminarundervisningen. Av disse hadde 54 studenter et oppmøte på minst 8 av 12 seminarer. Studenter med lavere oppmøte ble utelatt fra studien, siden vi ønsker å studere effekten av å delta på studentaktiv

seminarundervisning. Det var dermed 219 potensielle respondenter totalt. Av disse samtykte $85 \%(\mathrm{~N}=186)$ til å delta i studien. Tabell 1 gir en oversikt over antall respondenter i de ulike datainnsamlingene. Det var totalt 9 seminarlærere som underviste på seminarene $\mathrm{i}$ de to emnene. Av disse underviste 6 seminarlærere på testgruppene.

Tabell 1. Antall studenter på de ulike datainnsamlingene.

\begin{tabular}{|l|c|c|c|c|c|c|c|c|}
\hline & $\begin{array}{c}\text { Potensielle } \\
\text { respondenter }\end{array}$ & \multicolumn{2}{|c|}{$\begin{array}{c}\text { Andel } \\
\text { samtykke }\end{array}$} & \multicolumn{2}{|l|}{ Spørreskjema } & \multicolumn{2}{|c|}{ Kunnskapstest } & $\begin{array}{c}\text { Ordinær } \\
\text { eksamen }\end{array}$ \\
\cline { 3 - 9 } & $\mathrm{N}$ & $\%$ & Start & Slutt & $\begin{array}{c}\text { Pre- } \\
\text { test }\end{array}$ & $\begin{array}{c}\text { Posttest (gitt } \\
\text { svart på pretest) }\end{array}$ & \\
\hline Fysikk & 54 & 49 & 91 & 48 & 36 & 43 & 34 & 47 \\
\hline
\end{tabular}




\begin{tabular}{|l|c|c|c|c|c|c|c|c|}
\hline Kjemi & 165 & 137 & 83 & 137 & 93 & 131 & 91 & 137 \\
\hline Totalt & $\mathbf{2 1 9}$ & $\mathbf{1 8 6}$ & $\mathbf{8 5}$ & $\mathbf{1 8 5}$ & $\mathbf{1 2 9}$ & $\mathbf{1 7 3}$ & $\mathbf{1 2 5}$ & $\mathbf{1 8 4}$ \\
\hline
\end{tabular}

\section{Design}

Studentene fordelte seg på seminargrupper ut fra hvilke studieprogram de tilhørte, slik at det i stor grad var studenter med samme opptakskrav innenfor hver gruppe. I enkelte program med mange studenter ble det dannet to seminargrupper, der disse gruppene ble fordelt mellom test- og kontrollgrupper. I kjemi var det 9 seminargrupper, hvorav 5 fulgte studentaktiv undervisning (testgrupper) og 4 grupper fulgte undervisningen slik den har vært gjennomført tidligere år (kontrollgrupper). Tilsvarende var det 4 seminargrupper i fysikk; 2 testgrupper og 2 kontrollgrupper. Det var tilfeldig hvilke type grupper seminarlærerne fikk tildelt og tilnærmet like undervisningserfaringer hos undervisere tilegnet test- og kontrollgrupper. Undervisnings øktene i testgruppene var organisert i tre ulike deler, der første og siste del bestod av studentaktive arbeidsformer. Undervisningsøktene i kontrollgruppene var hovedsakelig lærersentrert og fulgte i mindre grad en fast struktur. Strukturen på undervisningen i kontrollgruppene kunne dermed variere noe mellom de ulike seminarlærerne. Tabell 2 gir en oversikt over undervisningen i test- og kontrollgruppene. Test- og kontrollgruppene hadde tilgang til identiske oppgavesett for seminarene, slik at det var kun undervisningsformen som skilte gruppene fra hverandre.

\section{Studentaktive arbeidsformer}

I denne studien ble tre studentaktive arbeidsformer utprøvd: begrepsoppgaver, Pick me! og speed-date. Valget var basert på positive erfaringer med arbeidsformene, og i tillegg ønsket vi å bruke arbeidsformer som la til rette for muntlig aktivitet, samarbeid og økt begrepsforståelse. Seminarlærerne som underviste testgrupper fikk opplæring i undervisningsmetodene og tilgang til en skriftlig beskrivelse av undervisningsoppleggene.

Begrepsoppgaver fokuserer på forståelse av begreper, og kan normalt løses uten avansert regning. Oppgavene har fokus på dybdelæring og at studentene får øvelse i å uttrykke faglig forståelse. I testgruppene ble studentene satt i grupper for å diskutere seg frem til løsninger på oppgaver, mens det ikke var lagt opp til samarbeid mellom studentene i kontrollgruppene.

Studentene i testgruppene deltok aktivt i oppsummeringen av oppgavene, sammenlignet med en hovedsakelig lærersentrert oppsummering i kontrollgruppene. Målet med begrepsoppgavene var at studentene skulle jobbe grundig med de viktigste begrepene og at dette skulle bidra til bedre begrepsforståelse og dybdekunnskap.

I gjennomføringen av arbeidsformen Pick me! forbereder studentene seg hjemme på oppgaver de presenterer for andre studenter på seminaret. På selve seminaret må studentene markere et minimum av oppgaver de vil kunne presentere. Vi valgte å bruke to variasjoner av Pick me! hvorav den ene var presentasjon av oppgaver på tavla i plenum, og den andre presentasjon i mindre grupper på 3-4 studenter. Seminarlærer eller gruppen selv velger hvem som presenterer de ulike oppgavene. Målet med denne metoden var at den skulle bidra til at studentene kommer forberedt til seminarundervisningen. Metoden bidrar også til at undervisningen blir tilpasset den enkelte student sitt kunnskapsnivå, ved at de velger mellom oppgaver de klarte å løse på forhånd.

I speed-date blir studentene satt sammen i par for å diskutere spørsmål som er gitt av seminarlærer. Etter 2-3 minutter dannes nye par og spørsmålet diskuteres om igjen med en annen student. Normalt $i$ en speed-date ble det gitt tre spørsmål som hvert ble diskutert med 
tre ulike medstudenter. Målet med metoden er økt begrepsforståelse og legger til rette for dybdelæring. Studentene får også øvelse i å uttrykke seg faglig.

Tabell 2. Organisering av undervisningen i seminargruppene.

\begin{tabular}{|l|l|l|l|}
\hline $\begin{array}{l}\text { Test- } \\
\text { gruppe }\end{array}$ & $\begin{array}{l}\text { Studentaktiv del } \\
\text { Studenter diskuterer } \\
\text { begrepsoppgaver i } \\
\text { grupper. Gjennomgang i } \\
\text { plenum hvor gruppene } \\
\text { presenterer sine svar. }\end{array}$ & $\begin{array}{l}\text { Studentene løser } \\
\text { seminaroppgaver. } \\
\text { Seminarlærer hjelper til } \\
\text { ved behov. }\end{array}$ & $\begin{array}{l}\text { Studentaktiv del } \\
\text { Valg av en metode: } \\
\bullet\end{array}$ \\
$\bullet$ & Pick me! i plenum \\
$\bullet$ & Pick me! i grupper \\
\hline $\begin{array}{l}\text { Kontroll- } \\
\text { gruppe }\end{array}$ & $\begin{array}{l}\text { Studentene arbeider med } \\
\text { begrepsoppgaver. } \\
\text { Seminarlærer gjennomgår } \\
\text { oppgaver ved behov. }\end{array}$ & $\begin{array}{l}\text { Studentene løser } \\
\text { seminaroppgaver. } \\
\text { Seminarlærer hjelper til } \\
\text { ved behov. }\end{array}$ & $\begin{array}{l}\text { Seminarlærer gjennomgår } \\
\text { utvalgte oppgaver på tavla } \\
\text { etter behov. }\end{array}$ \\
\hline
\end{tabular}

\section{Måleinstrumenter}

Datamaterialet i denne studien består av både kvantitative og kvalitative data. Det ble gjennomført spørreundersøkelse og kunnskapstest ved semesterstart (første forelesning) og ved slutten av semesteret (siste forelesning). Studentenes eksamenskarakter ble også inkludert i datamaterialet. Det ble gjennomført et fokusgruppeintervju av seminarlærerne i testgruppene ved semesterslutt, hvor fem av seks mulige seminarlærere deltok. Figur 1 viser tidslinje for de ulike datainnsamlingene.

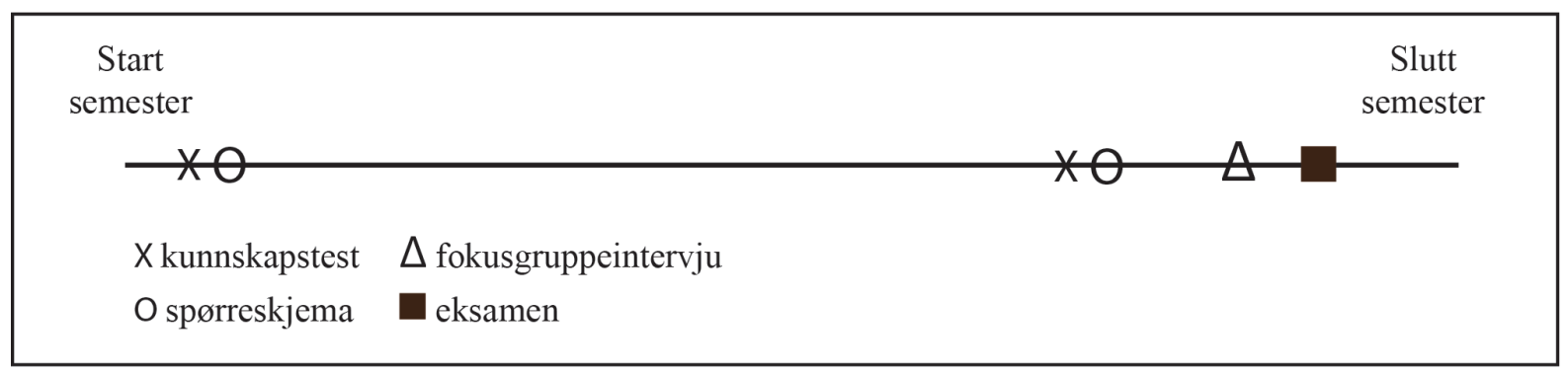

Figur 1. Tidslinje over datainnsamling.

Spørreskjemaene inneholdt flervalgspørsmål hvor studentene ble bedt om å ta standpunkt til påstander om faglig bakgrunn, læring, motivasjon, samarbeid og klassemiljø. Det var i tillegg inkludert enkelte åpne spørsmål. Studentene i testgruppene fikk noen ekstra spørsmål på siste spørreskjema knyttet til de studentaktive arbeidsformene. Påstander som studentene skulle ta stilling til ble målt i en 5-punkts Likertskala.

Kunnskapstestene som ble benyttet var «Concept Inventory» tester, hvor studentene svarer på identiske tester før og etter at undervisning har funnet sted. I fysikk ble det brukt en norsk versjon av Force Concept Inventory (FCI) (Aasen, 2013; Angell, 2013). I kjemi ble Chemistry Concept Inventory (CCI) benyttet (Krause, Birk, Bauer, Jenkins, \& Pavelich, 2004). CCI ble oversatt og modifisert til norsk av en av forfatterne. Begge testene var flervalgstester. Vi valgte å bruke resultatene fra kunnskapstestene og skriftlig eksamen som mål på læringseffekt. 


\section{Analysemetoder}

Analysen av de kvantitative dataene ble gjort i IBM SPSS (versjon 23) med deskriptiv statistikk, student t-tester og ANCOVA-test for sammenligning av uavhengige grupper. Den statistiske analysen tar høyde for at det vil finnes variasjon i forkunnskapsnivå mellom testog kontrollgrupper som øvrig design ikke vil kunne utjevne.

I de åpne spørsmålene i spørreskjemaet vurderte studentene de tre studentaktive arbeidsformene i tillegg til hvordan seminarundervisningen påvirket deres motivasjon og faglige læringsutbytte. Fokusgruppeintervjuet med seminarlærerne fokuserte på hvordan seminarlærerne vurderte de ulike arbeidsformene, spesielt hvordan arbeidsformene påvirket studentenes læring og sosiale relasjoner i seminargruppen. Intervjuet ble tatt opp på lydfil og transkribert. De åpne spørsmålene fra spørreundersøkelsene og fokusgruppeintervjuet ble hver for seg analysert kvalitativt med en temabasert analytisk tilnærming (Thagaard, 2013). Etter flere gangs gjennomlesninger, gjorde vi meningsfortetninger og analyse av meningsinnholdet. De tematiske kategoriene som ble valgt var «klassemiljø», «læring» og «gjennomføring». Disse ble valgt ut som en kombinasjon av forskervalgte temaer og induktiv tilnærming til datamaterialet. Sitater fra både studenter og seminarlærere ble valgt ut for å belyse ulike vurderinger og synspunkter som kom frem i datamaterialet. Studien er godkjent av Norsk Senter for Forskningsdata (NSD) og innhenting og bruk av data er i tråd med deres retningslinjer.

\section{Resultater}

Studentenes faglige bakgrunn er vist i Tabell 3. Studentene i fysikk hadde ved sammenlikning av både karakter og fordypningsnivå et betydelig høyere og mindre variert forkunnskapsnivå sammenlignet med studentene i kjemi. Blant annet hadde $14 \% \mathrm{av}$ studentene på kjemiemnet ingen fordypning i kjemi fra videregående skole.

Tabell 3. Oversikt over høyeste fullførte kurs fra videregående opplæring

\begin{tabular}{|c|c|c|c|c|c|}
\hline \multicolumn{3}{|l|}{ Fysikk } & \multicolumn{3}{|l|}{ Kjemi } \\
\hline Fysikk & $\mathrm{N}$ & $\%$ & Kjemi & $\mathrm{N}$ & $\%$ \\
\hline Ingen fysikk & 0 & & Ingen kjemi & 19 & 14 \\
\hline Fysikk 1 & 8 & 17 & Kjemi 1 & 51 & 37 \\
\hline Fysikk 2 & 36 & 77 & Kjemi 2 & 65 & 47 \\
\hline Fysikk i høyere utdanning & 3 & 6 & Kjemi i høyere utdanning & 2 & 2 \\
\hline Sum & 47 & & Sum & 137 & \\
\hline Matematikk & & & Matematikk & & \\
\hline R1 eller S2 & 3 & 6 & R1 eller S2 & 72 & 53 \\
\hline R2 & 33 & 72 & $\mathrm{R} 2$ & 44 & 32 \\
\hline $\begin{array}{l}\text { Matematikk i høyere } \\
\text { utdanning }\end{array}$ & 10 & 22 & $\begin{array}{l}\text { Matematikk i høyere } \\
\text { utdanning }\end{array}$ & 21 & 15 \\
\hline Sum & 46 & & Sum & 137 & \\
\hline
\end{tabular}




\section{Laeringseffekt av studentaktive seminar}

Tabell 4 viser gjennomsnittlig score på de ulike kunnskapstestene og et gjennomsnitt av hver enkelt students normaliserte gevinst, $\mathrm{g}_{\mathrm{ave}}=<(\%$ posttest-\%pretest $) /(100-\%$ pretest $)>$.

I fysikk var gjennomsnittlig normalisert gevinst høyere for testgruppen (49,3\%) sammenlignet med kontrollgruppen $(39,3 \%)$. Resultatet for testgruppene er sammenlignbart med gjennomsnittlig gevinst på $48 \%$ fra et større studie av studentaktive arbeidsformer i fysikkundervisning (Hake, 1998). Student t-test for uavhengige grupper viser at forskjellen mellom test og kontrollgruppene i fysikk ikke var signifikant $(\mathrm{t}(32)=0,92, \mathrm{p}=0,365)$.

I kjemi var det derimot noe høyere læringsutbytte i kontrollgruppen ( $\left.g_{\text {ave }}=24,3 \%\right)$ sammenlignet med testgruppen $\left(\mathrm{g}_{\mathrm{ave}}=22,3 \%\right)$. Denne differansen var ikke statistisk signifikant $(\mathrm{t}(89)=-0,487, \mathrm{p}=0,628)$.

Tabell 4. Resultat av kunnskapstestene i form av gjennomsnittlig score, og gjennomsnittlig normalisert gevinst for studenter i test- og kontrollgrupper.

\begin{tabular}{|c|c|c|c|c|c|c|c|c|}
\hline & & \multicolumn{2}{|c|}{ Pretest } & \multicolumn{2}{|c|}{ Posttest } & \multicolumn{3}{|c|}{$\begin{array}{c}\text { Gjennomsnittlig normalisert } \\
\text { gevinst }\end{array}$} \\
\hline & & $\mathrm{N}$ & $\overline{\mathrm{x}}(\%)$ & $\mathrm{N}$ & $\overline{\mathrm{x}}(\%)$ & $\mathrm{N}$ & gave $_{\text {a }}(\%)$ & SD (\%) \\
\hline \multirow[b]{2}{*}{ Fysikk } & Test & 16 & 54 & 12 & $\overline{77}$ & 10 & 49,3 & 23,7 \\
\hline & Kontroll & 27 & 62 & 25 & $\overline{777}$ & 24 & 39,3 & 30,8 \\
\hline \multirow[b]{2}{*}{ Kjemi } & Test & 70 & 29 & 48 & 45 & 45 & 22,3 & 19,5 \\
\hline & $\overline{\text { Kontroll }}$ & 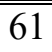 & 33 & $\overline{46}$ & 50 & 46 & 24,3 & 19,6 \\
\hline
\end{tabular}

Pretesten ga en indikasjon på at forkunnskapsnivået til studentene var høyere i

kontrollgruppene, og da spesielt i fysikk. Denne forskjellen kan mest sannsynlig forklares med at noen studieprogrammer rekrutterer studenter med bedre forkunnskaper enn andre.

Dette har vi ikke klart å ta hensyn til i vår studie. Eksamenskarakterene ved ordinær eksamen er gitt i Tabell 5. Gjennomsnittlig eksamenskarakter var litt høyere i testgruppene sammenlignet med kontrollgruppene i fysikk, mens vi så motsatt resultat i kjemi. På grunn av at test- og kontrollgruppene hadde ulik score på pretesten ble det foretatt en ANCOVA-test.

Det ble beregnet et estimert eksamensresultat med ANCOVA-test kontrollert for forkunnskaper (pretest). Når forkunnskaper ble tatt hensyn til, var gjennomsnittlig eksamenskarakter 0,36 høyere for fysikkstudentene $\mathrm{i}$ testgruppene enn for studentene $\mathrm{i}$ kontrollgruppene. Denne forskjellen i eksamenskarakter mellom studentgruppene på fysikkemnet var ikke statistisk signifikant $(F(1,44)=0,832, p=0,367)$. I kjemi ble det funnet en tilnærmet identisk gjennomsnittlig eksamenskarakter mellom studenter i test- og kontrollgrupper kontrollert for forkunnskaper. Det ble også foretatt ANCOVA-tester kontrollert for variablene karakter og faglig fordypning fra videregående skole, som også gir et bilde av kunnskapsnivået til studentene ved oppstart. Dette ga tilsvarende resultat som for pretest for begge emnene (resultat ikke oppgitt). Innledningsvis ble det kjørt Principal Component Analysis (PCA) på alle variablene i datasettet for å se om andre variable kunne forklare våre funn. Det ble ikke funnet andre årsakssammenhenger som kunne forklare våre resultater enn de som er presentert i artikkelen. 
Resultatene for vårt mål på læringseffekt viser en trend for fysikkemnet på gjennomgående bedre resultat $i$ testgruppene sammenlignet med kontrollgruppene. I tillegg var det ingen studenter i utvalget fra testgruppene i fysikk som strøk til eksamen. Disse trendene var ikke observert for kjemi.

Totalt 40 studenter i fysikk ble ekskludert fra utvalget på grunn av for lavt oppmøte. Disse hadde en gjennomsnittlig eksamenskarakter på 2,08 (ca. karakteren D). Dette er statistisk signifikant lavere enn gjennomsnittlig eksamenskarakter på 2,85 for studentene som var inkludert i utvalget målt med student t-test for uavhengige grupper $(\mathrm{t}(71)=2,325, \mathrm{p}=0,023)$. Gruppen som var ekskludert hadde gjennomsnittlig 54,9\% riktige svar på pretesten, mot tilsvarende snitt på 58,9\% for studentene i utvalget. Forkunnskapene til disse to gruppene vurderer vi dermed som sammenlignbare. Dette viser at studentene som var ekskludert fra utvalget ut fra lavt oppmøte på seminarundervisning presterte ca en karakter lavere på eksamen. Det ble derimot målt små forskjeller i gjennomsnittlig normalisert gevinst mellom disse gruppene på kunnskapstestene.

Tabell 5. Eksamensresultat ved ordinær eksamen.

\begin{tabular}{|c|c|c|c|c|c|c|c|c|}
\hline & \multicolumn{4}{|c|}{ Fysikk } & \multicolumn{4}{|c|}{ Kjemi } \\
\hline & \multicolumn{2}{|c|}{ Testgruppe } & \multicolumn{2}{|c|}{ Kontrollgruppe } & \multicolumn{2}{|c|}{ Testgruppe } & \multicolumn{2}{|c|}{ Kontrollgruppe } \\
\hline & $\mathrm{N}$ & $\%$ & $\mathrm{~N}$ & $\%$ & $\mathrm{~N}$ & $\%$ & $\mathrm{~N}$ & $\%$ \\
\hline A & 3 & 15 & 2 & 7 & 2 & 3 & 3 & 5 \\
\hline B & 2 & 10 & 6 & 22 & 6 & 8 & 5 & 8 \\
\hline C & 9 & 45 & 12 & 44 & 15 & 20 & 8 & 13 \\
\hline D & 3 & 15 & 2 & 7 & 6 & 8 & 15 & 24 \\
\hline $\mathbf{E}$ & 3 & 15 & 1 & 4 & 21 & 28 & 11 & 18 \\
\hline $\mathbf{F}$ & 0 & 0 & 4 & 15 & 25 & 33 & 20 & 32 \\
\hline Totalt & 20 & & 27 & & 75 & & 62 & \\
\hline $\begin{array}{l}\overline{\mathrm{x}}^{*} \text { Eksamenskarakter } \\
\text { (SD) }\end{array}$ & \multicolumn{2}{|c|}{$\begin{array}{c}2,95 \\
(1,23) \\
\end{array}$} & \multicolumn{2}{|c|}{$\begin{array}{c}2,78 \\
(1,45) \\
\end{array}$} & \multicolumn{2}{|c|}{$\begin{array}{c}1,49 \\
(1,47) \\
\end{array}$} & \multicolumn{2}{|c|}{$\begin{array}{c}1,61 \\
(1,50) \\
\end{array}$} \\
\hline $\begin{array}{l}\text { Estimert } \overline{\mathrm{x}}(\mathrm{SD}) \\
\text { kontrollert for pretest** }\end{array}$ & \multicolumn{2}{|c|}{$\begin{array}{c}3,06 \\
(0,294)\end{array}$} & \multicolumn{2}{|c|}{$\begin{array}{c}2,70 \\
(0,252)\end{array}$} & \multicolumn{2}{|c|}{$\begin{array}{c}1,55 \\
(0,165)\end{array}$} & \multicolumn{2}{|c|}{$\begin{array}{c}1,54 \\
(0,182)\end{array}$} \\
\hline
\end{tabular}

*Eksamensresultatene er kodet på følgende måte: $\mathrm{A}=5, \mathrm{~B}=4, \mathrm{C}=3, \mathrm{D}=2, \mathrm{E}=1$ og $\mathrm{F}=0$.

** 6 respondenter i fysikk og 6 respondenter i kjemi gjennomførte ikke pretesten. Disse er gitt gjennomsnittlig poengsum for pretest.

\section{Samarbeid og loering}

I de åpne spørsmålene fra spørreskjemaet trekker svært mange av studentene frem arbeidsformene speed-date og begrepsoppgaver som positive for gode faglige diskusjoner. Studentene begrunnet det med at diskusjoner i grupper førte til bedre forståelse av fagstoffet, og med at de fikk sett og diskutert ulike måter å løse en oppgave på. Studentene mente at gjennom å diskutere fikk de fjernet faglige misoppfatninger, og at de i ettertid husket fagstoffet bedre. Flere trakk også fram at de lærte av hverandre. Her er et utsagn som viser dette: «Jeg loerte mye av à snakke om samme tema til flere personer. Det gjorde at vi fikk se ei problemstilling fra flere sider. Det fikk meg til å huske bedre» Selv om mesteparten av studentene var positiv til samarbeidslæring, så var det enkelte som heller ønsket å arbeide individuelt. Dette argumenterte de hovedsakelig med at de opplevde å lære mer av å jobbe alene, eller at de mente undervisningen var for dårlig. 


\section{Evaluering av studentaktive arbeidsformer}

Studentenes evaluering av de studentaktive arbeidsformene er gitt i Tabell 6. Resultatene viser at studentene hadde et høyt selvopplevd læringsutbytte av arbeidsformen begrepsoppgaver i grupper, sammenlignet med aktivitetene Pick me! og speed-date.

Tabell 6. Rapportert læringsutbytte blant studentene som fulgte studentaktiv undervisning

\begin{tabular}{|l|l|c|}
\hline & \multicolumn{1}{|c|}{ Fysikk } & \multicolumn{1}{|c|}{ Kjemi } \\
\hline & $N=18$ & $N=46$ \\
& $M^{*}(S D)$ & $M^{*}(S D)$ \\
\hline Jeg lærte mye av å arbeide med begrepsoppgaver i grupper & $3,78(1,00)$ & $4,25(0,60)$ \\
\hline Jeg lærte mye av å bruke arbeidsmetoden «Pick me!» & $3,50(1,10)$ & $2,43(1,21)$ \\
\hline Jeg lærte mye av å bruke arbeidsmetode «speed-date» & $2,72(1,02)$ & $3,19(1,21)$ \\
\hline
\end{tabular}

*Studentene svarte på en skala fra 1 - "meget uenig" til 5 - "meget enig"

Samtlige studenter i både fysikk og kjemi var positive til begrepsoppgaver. Fra de åpne spørsmålene kom det fram at studentene syntes det var lærerikt å diskutere seg fram til svaret og å høre på forklaringer fra medstudenter. Dette mente de var med på å fjerne faglige misoppfatninger til fagstoffet. Studentene oppga at dette er en effektiv læringsmetode for å forstå nye begreper og å oppnå en dypere fagforståelse. Her er et utsagn fra studentene som viser dette: «Begrepsoppgavene gjorde slik at man forsto litt mer av hva man holdt på med.»

Studentenes vurderinger av arbeidsformen speed-date var blandet. Godt over halvparten opplevde metoden som lærerik, hvor de trakk frem at de lærte mye av å diskutere samme oppgave med flere personer. De fikk da fram flere faglige momenter fra medstudenter med alternative perspektiver og løsninger. Et utsagn som viser dette: «Da fikk man godt forklart av andre og neste person $i$ "daten" hadde alltid noe mer enn den forrige å komme med, så jeg følte det ga godt utbytte.». Det var også en relativ stor andel studenter som opplevde at de lærte lite av denne metoden, noe de begrunnet med at de syntes det var en ineffektiv læringsmetode hvor mye tid ble brukt til en relativ liten del av pensum. Enkelte trakk frem at de ikke lærte noe når ingen av partnerne visste svaret på oppgaven. Her et utsagn som illustrerer dette synspunktet: «Som regel var begge så usikker, så det endte med at vi satt og snakket om andre ting.». Det ble også framhevet at speed-date kun var lærerikt dersom spørsmålene var tilstrekkelig gode.

Studentene ga gode tilbakemeldinger på varianten av Pick me! med presentasjon i mindre grupper. De rapporterte at de følte seg trygge og lite stresset av å presentere oppgaver i en slik situasjon. Noen studenter uttrykte at de opplevde at det ble mer diskusjon rundt oppgavene når presentasjonen var i mindre gruppe sammenlignet med om den ble gjennomført i plenum. I tilbakemeldingene av varianten med presentasjon i plenum var det tydelig at mange studenter var svært ukomfortable. Denne kommentaren viser dette tydelig: «Likte ikke denne metoden av undervisningen. A måtte gå opp på tavlen var mer noe man grudde seg til, og denne undervisningsmetoden gjorde at man grudde seg til å dra på seminarene». Det var også en del studenter som mente de fikk et lavt læringsutbytte av å observere medstudenter presentere oppgaver i plenum. De trakk spesielt frem at medstudenter hadde begrensede fagkunnskaper, og at de manglet fagdidaktisk kompetanse til å formidle 
stoffet med tilfredsstillende kvalitet. Et mindretall av studentene var derimot positiv til presentasjon i plenum, og opplevde det som lærerikt både å se andre studenter løse oppgaver og å presentere selv.

\section{Studentenes evaluering av undervisningsopplegget som helhet}

Flere studenter i testgruppene i kjemi trakk frem at de forberedte seg bedre til seminarene på grunn av den studentaktive undervisningen. Disse studentene begrunnet dette med at de enten kunne bli trukket ut til å presentere i plenum, eller at de ønsket å kunne bidra i gruppearbeidet. Her er et sitat som underbygger dette: «Man følte at man ønsket å vaere forberedt til timene slik at man kunne bidra i gruppen». Mange studenter påpekte at spørsmålene og oppgavene til speed-date og Pick me! ikke var tilstrekkelig gode. Disse studentene mente at oppgavene var for enkle og at de brukte liten tid på å diskutere seg frem til svarene. Et representativt utsagn for disse studentene: «Dessuten kunne jeg tenke meg at spørsmålene kanskje burde voere litt mer komplisert og ikke så åpenbart for de som har lest for eksempel relevant fagstoff $i$ boken. Med andre ord synes jeg de burde vare litt mer grubleoppgaver».

I de åpne spørsmålene fra spørreskjemaet ble det gitt tilbakemeldinger fra studentene som kan tolkes som at de savnet en tydeligere klasseledelse. Her ble det nevnt at organisering av de ulike aktivitetene tok tid, og at ikke-faglig prat og støy oppstod under aktivitetene eller ved dødtid. Eksempler som ble tolket som svak klasseledelse var at undervisningen kunne skli ut med at studentene ikke fulgte undervisningsopplegget. Et utsagn fra studentene om klasseledelse: «Undervisningsformene virker gode i teorien, men som følge av mangel på gjennomføringskraft $i$ seminargruppen vil nok effekten av dette vore mangelfull.» Studentene oppga at organiseringen av undervisningen bedret seg utover i semesteret. I noen tilbakemeldinger ble det kommentert at det ble for mange undervisningsformer i et seminar, og at dette også bidro til uro og tap av undervisningstid. Her er to studentkommentarer som viser dette: «...jeg synes at det var alt for mye som skjedde $i$ løpet av de to timene.» og «Tidvis endel tull med de forskjellige seminarformene.»

\section{Studentaktive arbeidsformer sin innvirkning på klassemiljøet.}

I det avsluttende spørreskjemaet var to av påstandene knyttet til klassemiljøet: "det var et godt sosialt miljø $i$ seminargruppen" og "jeg ble godt kjent med de andre studentene $i$ seminargruppene". Disse viste tilfredsstillende indre konsistens (Cronbach alfa $>0,6$ ) og ble slått sammen til felles variabel «klassemiljø», med ny kombinert skala 2-10 med midtpunkt på 6. Studentene på fysikkemnet hadde en gjennomsnittlig score på 8,06 i testgruppene mot 6,81 i kontrollgruppene, og med tilsvarende forskjell for studentene i kjemiemnet med 8,43 mot 7,27. Student t-tester for uavhengige grupper viser en signifikant forskjell mellom testog kontrollgruppene i begge fag (fysikk: $\mathrm{t}(32)=2,17, \mathrm{p}=0,038$, og kjemi: $\mathrm{t}(89)=2,99 \mathrm{p}=0,004$ ). Scoren på variabelen «klassemiljø» var dermed klart høyere i testgruppene sammenlignet med kontrollgruppene. Det var ikke inkludert åpne spørsmål innenfor temaet klassemiljø i spørreskjemaet, men svært mange studenter som hadde fulgt studentaktiv undervisning responderte på andre spørsmål at de likte å samarbeide med medstudenter. Vi tolket dette som at studentene var positive til den økte graden av samarbeidslæring i testgruppene. Et eksempel på et slikt utsagn er: «Jeg ble bedre kjent med folk og deres kunnskaper som var med å skape større samhold...». Det ble ikke funnet noen forskjeller mellom studentene i 
test- og kontrollgruppene på svarene fra påstander om motivasjon, samarbeid med medstudenter og tidsbruk.

\section{Seminarlcerernes evaluering av undervisningen}

I fokusgruppeintervjuet ble seminarlærerne for testgruppene bedt om å fortelle om sine opplevelser knyttet til innføring av de studentaktive arbeidsformene. Alle seminarlærerne uttrykte at de var fornøyde med metoden begrepsoppgaver. Seminarlærerne mente at det var viktig at begrepsoppgavene inneholdt lite teknisk utregning og fokuserte på forståelse av faget. Undervisningsformen speed-date ble oppfattet som den mest ukjente av de valgte aktivitetene, og i starten av semesteret ble speed-date opplevd som både stressende og uoversiktlig av lærerne. Gjennomføringen av aktiviteten mente de gikk bedre utover i semesteret når både studentene og seminarlærerne hadde fått erfaring med undervisningsmetoden. Seminarlærerne ønsket å benytte seg av speed-date i videre undervisning, men poengterte at det er viktig med erfaring for å lede slike aktiviteter på en god måte. Metoden Pick me! med presentasjon i plenum ble vurdert som stressende for studentene på grunn av personfokuset når enkeltstudenter skulle presentere løsninger i plenum, og seminarlærerne ønsket å modifisere undervisningsformen. Noen eksempel på forslag for å fjerne stress var at studentene kunne presentere i par, og færre presentasjoner i plenum sammenlignet med i små grupper.

Det var en bred enighet blant seminarlærerne om at de studentaktive arbeidsformene var med å skape et godt og inkluderende arbeidsmiljø på seminarene. Det ble trukket fram at alle studentene ble inkludert i gruppene og at ingen studenter ble sittende alene. Dette gjaldt både for seminargrupper som tilhørte ett studieprogram, men også for seminargrupper som hadde studenter fra ulike program. Studentene ble beskrevet av lærerne som «komfortabel $i$ gruppen», «studentene turte å ta ordet» og som å «trives» i undervisningen. De seminarlærerne som hadde erfaring fra seminarundervisning beskrev et arbeidsmiljøet med både mer og bedre interaksjon mellom studentene etter omleggingen til studentaktive seminar. Den økte interaksjonen mellom studentene var ikke opplevd som støy og lærerne mente at studentene først og fremst snakket om faget. Det var først når studentene var ferdige med undervisningsaktivitet før oppsatt tid at ikke-faglig prat ble observert.

Studentene ble beskrevet av lærerne å følge samarbeidsbaserte læringsstrategier ved at studentene «diskuterte», «forklarte», «spurte hverandre» og «supplerte hverandre». Seminarlærerne observerte at det var naturlig for studentene å arbeide sammen og trakk fram ordet «team spirit» i denne sammenhengen. Det ble uttrykt av noen lærere at studentene foretrakk å samarbeide også når det var mulighet å arbeide individuelt. I tillegg til et godt miljø blant studentene, mente seminarlærerne at de studentaktive seminarene la til rette for en god lærer-studentkontakt. Seminarlærerne så på arbeidsformene som verktøy til å få til en bedre faglig samtale med studentene. De som hadde undervist på seminar tidligere var positive til en forbedret kontakt med studentene, og uttrykte at det tidligere hadde vært vanskelig å oppnå tilstrekkelig faglig interaksjon i undervisningen. Det var bred enighet blant seminarlærerne at de ønsket å benytte seg av studentaktive arbeidsformer i fremtidig undervisning, men at de ville bruke egne erfaringer for å tilpasse undervisningen. Seminarlærerne opplevde også at studentene kom bedre forberedt til seminarundervisningen etter omleggingen. 
Det ble rapporterte om et lite omfang av negative tilbakemeldinger til seminarlærerne fra enkeltstudenter på testgruppene. Disse ble beskrevet å komme fra studenter som syntes undervisningsformene var utfordrende, eller når studentene ikke opplevde studentaktive læringsformer like meningsfulle som lærerstyrte og individuelle aktiviteter. Slike tilbakemeldinger påvirket undervisningen til seminarlærere med lite erfaring, som eksempelvis sluttet med at studentene presenterte i plenum.

Den skriftlige beskrivelsen for seminarundervisningen ble sett på som positiv av seminarlærerne, og de oppga å benytte den både i planlegging og gjennomføring av undervisningsøktene. Seminarlærerne med mindre erfaring følte seg mer bundet av instruksen i starten av semesteret. For seminarlærerne som var usikker i klasseledelse, kunne det enkelte ganger være vanskelig å følge de planlagte læringsaktivitetene. Disse ga uttrykk for at de ikke følte seg komfortable med å stille krav til studentene ved å «presse» eller «mase». Et sitat fra seminarlærer med lite erfaring fra tidligere belyser dette: «Jeg tror jeg var mer nervøs enn dem (studentene) på første gruppetime.» Seminarlærere med tidligere erfaring uttrykte at de i starten av sin undervisningskarriere hadde opplevd det som utfordrende å skulle undervise uten opplæring. Sitater fra to ulike undervisere om sine tidligere erfaringer var: «Jeg husker jeg kjente meg veldig forlatt første gangen jeg skulle ha seminar.» og «Så det var jo egentlig bare hoppe i det og hjelpe de som stiller spørsmål og ta det derfra.»

\section{Diskusjon}

Denne studien har analysert hvilken effekt innføring av studentaktive arbeidsformer i seminarundervisning har hatt for læringsutbyttet og klassemiljøet i to ulike STEM-fag. Det finnes svært mange ulike måter å aktivisere studenter i høyere utdanning, og i denne studien ble det valgt å se på tre bestemte undervisningsaktiviteter. Vi vil være forsiktige med å generalisere våre resultater ut fra begrensningen i antall studentaktive arbeidsformer, det korte tidsaspektet og at studien inneholder kvalitative data.

Vi kan ikke ut fra vårt datamateriale entydig fastslå at omlegging til studentaktive seminar førte til en høyere læringseffekt for studentene. Det er en tendens til økt læringsutbytte for studenter som fulgte studentaktive seminarer i fysikk, med 0,36 i økt bedre gjennomsnittlig eksamenskarakter og liknende trend i kunnskapstestene. Studentene i kjemi viste derimot marginale forskjeller i læringseffekt, selv om undervisningsoppleggene for fysikk- og kjemiemnet var ganske like. Det er vanskelig å si noe sikkert om hva som forårsaker disse forskjellene, og det kan også være sammensatte årsaker til vårt resultat. En klar forskjell mellom studentgruppene i fysikk og kjemi var variasjonen i forkunnskapsnivå fra videregående skole. Studentene på kjemiemnet hadde både et lavere og mer variert forkunnskapsnivå sammenlignet med studentene på fysikkemnet. Dette kan ha gjort det vanskeligere å tilpasse seminarundervisningen til riktig nivå for studentgruppene i kjemi. Læringsformene vi valgte å bruke i studien krevde at studentene deltok i faglig diskusjon, noe som forutsetter at studentene har et minimum av forkunnskaper. Faglig svake studentene, som det var større andel av på kjemiemnet, kan ha hatt utfordringer med å delta aktivt i den studentaktive undervisningen. Dette underbygges også av enkelte tilbakemeldinger fra studentene, eksempelvis om aktiviteten speed-date. Et annet aspekt er at en betydelig andel av studentene på fysikkemnet var ekskludert fra utvalget på grunn av lavt oppmøte på seminarundervisningen. Vi vet dermed ikke hvordan et høyere oppmøte fra denne studentgruppen ville ha påvirket våre resultater. I fysikkemnet var arbeidsformen 
begrepsoppgaver allerede innført i undervisningen semesteret før, mens det var første gang denne aktiviteten ble tatt i bruk i kjemiemnet. Dette kan ha ført til at omleggingen var mer utfordrende for lærerne på kjemiemnet enn i fysikkemnet, og at dette påvirket undervisningen.

Det er tidligere rapportert om mange studier som viser at studentaktive arbeidsformer øker læringsutbytte i høyere utdanning (Freeman et al., 2014). Vår studie viste ingen signifikant økning i læringsutbyttet, men viste bedret sosialt klassemiljø og mange studenter ga utrykk for at de likte omleggingen til mer studentaktiv undervisning. I en annen studie fra høyere utdanning hvor det ble innført studentaktiv undervisning, ble det rapportert om økt tilfredshet og engasjement, selv om man ikke fant en signifikant økning i læringseffekt (Lucke, Dunn \& Christie, 2017). Dette viser at selv om omlegging til mer studentaktiv undervisning ikke umiddelbart fører til dokumentert læringseffekt, kan de gi andre positive effekter. At vår studie ikke kunne vise til en slik statistisk signifikant økning kan ha sammenheng med at det er utfordrende å legge om til studentaktiv undervisning. Felder \& Brent (1996) beskriver at omlegging fra lærer- til studentsentret undervisning ikke gir umiddelbart og automatisk læringseffekt, da omlegging til en ny undervisningssituasjon er krevende for både lærere og studenter. I vår omlegging av seminarundervisningen viser datamateriale at det var spesielt tre momenter som var utfordrende. Enkelte seminarlærere opplevde at det var krevende å utøve god klasseledelse, kvaliteten på undervisningsmaterialet var ikke tilstrekkelig god, og det var lagt opp til mange ulike aktiviteter i hvert seminar. Vi tror at læringseffekten for studentene i emnene vil kunne øke ved å ta tak i disse elementene. Studentene i studien var tydelige på at deres opplevde læringsutbytte varierte stort mellom de ulike metodene. Disse tilbakemeldingene vil være viktige for videre utvikling av undervisningen.

Det er usikkert i hvor stor betydning to ukentlige timer seminarundervisning påvirker læringen i disse to emnene. Vi har ikke vurdert læringselementer som forelesninger, kollokvier, laboratorieundervisning eller andre aspekter som påvirker læringsutbyttet til studentene. Det kan også stilles spørsmål om i hvilken grad resultatene fra kunnskapstestene og skriftlig eksamen måler læringseffekten av endret undervisningsform, og dermed om det mangler samstemming av undervisning og vurderingsform. Det kan hende en annen vurderingsform som for eksempel muntlig eksamen ville vært bedre, siden studentene ble trent i å diskutere i de studentaktive seminargruppene. Studenter som var ekskludert fra utvalget i fysikkemnet fikk signifikant dårligere eksamensresultat sammenlignet med studentene i studien. Siden gjennomsnittlig normalisert gevinst på kunnskapstestene var omtrent lik mellom disse gruppene, er det ikke entydig i hvilken grad antall oppmøter påvirker læringseffekten. Vi vil være forsiktige med å trekke konklusjoner basert på vårt datagrunnlag, men ved at eksamen dekker en større del av pensum enn kunnskapstestene kan forskjeller i eksamensresultat tolkes som at seminarundervisningen hadde påvirket studentenes læring positivt.

Studien viser også at studenter som fulgte studentaktive seminarer kom bedre forberedt til undervisningen sammenlignet med kontrollgruppen. Tidligere semestre har seminarlærerne opplevd at manglende forberedelse blant studentene har hemmet undervisningen. Omleggingen ser dermed ut til å ha bidratt positivt til å endre studentadferden og dermed forbedre kvaliteten på seminarene. 
Våre funn i datamateriale fra både studenter og seminarlærere, viser tydelig at de studentaktive arbeidsformene førte til et bedre klassemiljø. Det store flertallet av studentene satte pris på å samarbeide med medstudenter i seminarene. Dette er i samsvar med studien til Cavanagh (2011) som viser at studentene verdsetter elementer av samarbeidslæring i undervisningen. Et godt klassemiljø og bruk av studentaktive arbeidsmåter vil kunne ha positive effekter både i et kort og et mer langsiktig perspektiv. På kort sikt kan studentene få en bedre studiehverdag ved at de trives bedre i undervisningen, og ved at de får bedre sosiale relasjoner til sine medstudenter (Braxton, Milem, \& Sullivan, 2000). Det vil også kunne ha betydning i et lengre løp siden læringsmiljøet og undervisningsmetoder har stor betydning for å forhindre frafall i STEM-fagene (Ulriksen, Madsen, \& Holmegaard, 2010). God samhandling mellom studentene og mellom studentene og ansatte har vist seg å bidra til redusert frafall (Ulriksen et al., 2010). Våre funn om at studentaktive seminar ga bedre klassemiljø og forbedret kontakten mellom lærere og studenter kan på sikt bidra til å redusere frafallet blant studentene.

I denne studien fikk seminarlærerne opplæring og oppfølging underveis i semesteret, i tillegg til et helhetlig undervisningsopplegg å forholde seg til. Seminarlærerne uttrykte at dette er uvanlig, og flere hadde savnet og hatt behov for opplæring tidligere. I tillegg viser vår studie at hovedvekten av seminarlærene ikke hadde formell pedagogisk kompetanse. Mangel på opplæring og undervisningskompetanse hos seminarlærere er ikke optimalt for å kunne gi et godt undervisningstilbud. Dette vil blant annet kunne komme til uttrykk som svak klasseledelse, som vi finner eksempler på i vårt materiale. Vi tror at manglende didaktisk kompetanse hos underviseren vil gjøre det vanskeligere å gjennomføre god studentaktiv undervisning, siden dette krever at underviseren kan lede og veksle mellom ulike aktiviteter. For å forbedre kvaliteten på seminarundervisningen ser vi dermed betydningen av bedre opplæring og oppfølging av lærerne. Vi tror at tiltak som eksempelvis fører til at seminarlærere diskuterer og reflekterer rundt egen undervisning som del av Scholarship of Teaching and Learning - SoTL (Boyer, 1991) kan være verdifullt for utviklingen av god undervisningskvalitet.

Våre funn viser at studentaktive seminarer fører til et bedre klassemiljø, men at det er nødvendig med videre utviklingsarbeid og forskning for å forstå hvilken innvirkning studentaktive seminarer har for studentenes læring. 


\section{Referanseliste}

Aasen, T. F. (2013). Force Concept Inventory - En undersøkelse av mekanikkforståelsen til FYS1000studenter. (Master), UiO, Oslo.

Angell, C. (2013). [Privat kommunikasjon].

Angell, C., Bungum, B., Henriksen, E. K., Kolst $\varnothing$, S. D., Persson, J., \& Renstrøm, R. (2011). Fysikkdidaktikk. Kristiansand: Høyskoleforlaget.

Boyer, E. L. (1991). The Scholarship of Teaching: From "Scholarship Reconsidered: Priorities of the Professoriate.". College Teaching, 39(1), 3.

Braxton, J. M., Milem, J. F., \& Sullivan, A. S. (2000). The Influence of Active Learning on the College Student Departure Process. The Journal of Higher Education, 71(5).

Cavanagh, M. (2011). Students' experiences of active engagement through cooperative learning activities in lectures. Active Learning in Higher Education, 12(1).

Chace, J. F. (2014). Collaborative Projects Increase Student Learning Outcome Performance in Nonmajors Environmental Science Course. Journal of College Science Teaching, 43(6), 6.

Crouch, C. H., \& Mazur, E. (2001). Peer Instruction: Ten years of experience and results. Am. J. Phys., 69(9).

Derting, T. L., Ebert-May, D., Henkel, T. P., Maher, J. M., Arnold, B., \& Passmore, H. A. (2016). Assessing faculty professional development in STEM higher education: Sustainability of outcomes. Science Advances, 2(3). doi:10.1126/sciadv.1501422

Exley, K., \& Dennick, R. (2004). Small Group Teaching. London: RoutledgeFalmer.

Felder, R. M., \& Brent, R. (1996). Navigating the Bumpy Road to Student-Centered Instruction. College Teaching, 44(2), 5.

Foldnes, N. (2016). The flipped classroom and cooperative learning: Evidence from a randomised experiment. Active Learning in Higher Education, 17(1), 11.

Freeman, S., Eddy, S. L., McDonough, M., Smith, M. K., Okoroafor, N., Jordt, H., \& Wenderoth, M. P. (2014). Active learning increases student performance in science, engineering, and mathematics. PNAS, 111(23).

Hake, R. R. (1998). Interactive-engagement versus traditional methods: A six-thousand-student survey of mechanics test data for introductory physics courses. Am. J. Phys., 66(1).

Hardman, J. (2016). Tutor-student interaction in seminar teaching: Implications for professional development. 17(1), 63-76. doi:10.1177/1469787415616728

Henriksen, E. K., \& Angell, C. (2010). The Role of "Talking Physics" in an Undergraduate Physics Class Using an Electronic Audience Response System. Physics Education, 45(3), 278-284. doi:10.1088/0031-9120/45/3/008

Herrmann, K. J. (2013). The impact of cooperative learning on student engagement: Results from an intervention. Active Learning in Higher Education, 14(3).

Krause, S., Birk, J., Bauer, R., Jenkins, B., \& Pavelich, M. (2004). Development, Testing and Application of a Chemestry Concept Inventory. Paper presented at the 34th ASEE/IEEE Frontiers in Education Conference, Savannah, GA.

Leach, J., \& Scott, P. (2003). Individual and Sociocultural Views of Learning in Science Education. Science \& Education, 12, 24.

Lucke, T., Dunn, P.K, \& Christie, M. (2017) Activating learning in engineering education using ICT and the concept of 'Flipping the classroom', European Journal of Engineering Education, 42:1, 45-57, DOI: 10.1080/03043797.2016.1201460

Thagaard, T. (2013). Systematikk og innlevelse : en innføring i kvalitativ metode (4. utg. ed.). Bergen: Fagbokforl.

Ulriksen, L., Madsen, L. M., \& Holmegaard, H. T. (2010). What do we know about explanations for drop out/opt out among young people from STM higher education programmes? Studies in Science Education, 46(2). 